\title{
Phenotypic Diversity of Ethiopian Coffee (Coffea arabica L.) Accessions Collected from Limmu Coffee Growing Areas Using Multivariate Analysis
}

\author{
Lemi Beksisa*, Tadesse Benti, Getachew Weldemichael \\ Ethiopian Institute of Agricultural Research, Jimma Agricultural Research Center, Jimma, Ethiopia
}

Email address:

lbeksisa@gmail.com (L. Beksisa)

${ }^{*}$ Corresponding author

\section{To cite this article:}

Lemi Beksisa, Tadesse Benti, Getachew Weldemichael. Phenotypic Diversity of Ethiopian Coffee (Coffea arabica L.) Accessions Collected from Limmu Coffee Growing Areas Using Multivariate Analysis. American Journal of BioScience. Vol. 9, No. 3, 2021 , pp. 79-85.

doi: 10.11648/j.ajbio.20210903.12

Received: April 17, 2021; Accepted: May 11, 2021; Published: May 20, 2021

\begin{abstract}
Forty seven Coffea arabica L. germplasm accessions collected from Limmu district were field evaluated from 2004/5 to 2013/14 with two commercial check varieties at Agaro Agricultural Research sub center in single plot. The objective of the experiment was to assess the variability among the accessions using quantitative traits. Data for about eight quantitative traits were recorded only once in experimental period, while the yield data were recorded for six consecutive cropping seasons. Cluster, genetic divergence, and principal component analysis were used to assess the variability among the genotypes. The results revealed that average linkage cluster analysis for nine traits grouped the germplasm accessions in to three clusters. The number of accessions per cluster ranged from three in cluster III to 25 in cluster II. The clustering pattern of the coffee accessions revealed that the prevalence of moderate genetic diversity in Limmu coffee for the characters studied. The maximum inter-cluster distance was observed between clusters II and III; whereas the minimum inter-cluster distance was observed between clusters I and II. The study highlighted the possibility of using accessions of the distant clusters as potential candidates for the genetic improvement of Limmu coffee through hybridization. Moreover, the principal component analysis showed that the first four PCs extracted about $82 \%$ of the total variance of the 49 coffee germplasm accessions and also confirmed moderate diversity among the germplasm accessions since the entire variation cannot be explained in terms of few PCs. This, in turn, indicates that the involvement of a number of traits in contributing towards the overall diversity.
\end{abstract}

Keywords: Coffea Arabica, Clustering and Principal Component, Gomma Woreda, Quantitative Traits

\section{Introduction}

Coffee (Coffea arabica L.) is native to the highlands of Southwest Ethiopia (Sylvain, 1958) and belongs to the genus Coffea, in the family Rubiaceae. More recently combination of morphological and molecular data set revealed that Rubiceae (Coffeaeae) is enlarged to encompass eleven genera [5]. Coffee production in the center of origin, Ethiopia, has vital role for the economy, ecology, socio-cultural and spiritual life of the people. Nationally, it is estimated that about 4.5 million farming households are involved in coffee production activities [23]. From the economic point of view, the coffee sector contributes for about $4-5 \%$ to the country's growth domestic product [7] and provides an income for about 25 million people who are engaged in coffee production, processing, distribution, trading, exporting and other related activities [25]. Coffee is Ethiopia's most important export commodity, accounting for about 27 to 31 percent of the country's commodity exports averaged over the last four years [7].

Ethiopia ranks first in Africa and fifth in the world after Brazil, Vietnam, Colombia and Indonesia in coffee production and is the tenth coffee exporter with less than 5 percent share of the world. During 2020 cropping season, the total area under production estimated to 540,000 hectares and the production is estimated to be 450,000 metric tons [7]. In Ethiopia, coffee grows under a wide range of environmental conditions between altitudinal ranges from 550 to $2750 \mathrm{~m}$ 
above sea level. However, the most important coffee producing environment in the country is between altitudinal range from 1500 to $2500 \mathrm{~m}$ above sea level with ideal minimum and maximum air temperature of 15 and $30 \mathrm{C}$, respectively [2].

Though Ethiopia is endowed with suitable environments and immense genetic diversity for coffee production, the productivity of the crop per unit area remains very low, which is less than 0.7 ton/ha. Among others, the major contributing factors for low production and productivity of the Arabica coffee in the country is use of unimproved coffee landraces, traditional coffee management practice, improper harvesting and post-harvest practices [24]. Thus, it is a high time to improve the coffee productivity of the country by developing high yielding disease resistant and high quality coffee varieties through selection and hybridization.

The success of any breeding program depends largely upon the amount of genetic variability present in the population and the extent to which the desired traits are heritable. In this regard, knowledge on the pattern of variation for important morpho-agronomic traits is essential for a proper management and a better exploitation of the available gene pool [12]. However, despite Ethiopia is gifted with a huge coffee genetic resources to improve the productivity as well as the quality of coffee, the available potential have not been exploited to the desired level. Therefore, collection and characterization of the available coffee genetic resource is paramount of paramount importance to exhaustively use the available resource for further breeding program.

In line with this, few investigators in Ethiopia characterized some of Ethiopian coffee accessions for its quantitative characters. For instance, Olika [18], Getachew et al. [10], Mesfin et al. [16], Lemi and Ashenafi [13], Masreshaw [15] and Desalegen [6] reported the existence of variability for quantitative traits among coffee accessions collected from Limmu Kosa (Limmu set II), Gomma (Limmu set IV), Southern Ethiopia, east Wollega, Yayu forest of Ethiopia and Amaro Kello, respectively. However, although coffee from Limmu coffee is known for its peculiar winey flavor and fetches premium price in the world market, the 49 coffee accessions which were collected form Gomma (Limmu set III), were not yet systematically characterized for quantitative traits. Therefore, this study was conducted to assess the extent of genetic variation existed among the coffee accessions collected from this area using multivariate analysis.

\section{Materials and Methods}

\subsection{Description of the Study Site}

The experiment was conducted at Agaro agricultural research sub center of Jimma Agricultural Research Center. The center is located at $7^{\circ} 50$ ' 35 " $-7^{\circ} 51$ ' $00^{\prime}$ N latitude and $36^{\circ} 35^{\prime} 30^{\prime \prime} \mathrm{E}$ longitude and at an altitude of 1630 meters above sea level (masl). It is located $397 \mathrm{~km}$ southwest of Addis Ababa and about $50 \mathrm{~km}$ west of Jimma town. The mean annual rainfall of the area is $1616 \mathrm{~mm}$ with an average maximum and minimum air temperatures of $28.4^{\circ} \mathrm{C}$ and $12.4^{\circ} \mathrm{C}$, respectively. The major soil type is Mollic Nitisols with $\mathrm{pH}$ of 6.2 , organic matter $7.07 \%$, nitrogen $0.42 \%$, phosphorus $11.9 \mathrm{ppm}$, CEC $39.40 \mathrm{~mol}(+) / \mathrm{kg}$ [8].

\subsection{Experimental Material}

Forty seven C. arabica L. germplasm accessions collected during 2004/5 from the Gomma district in Jimma zone and two commercial varieties were used for this study (Table 1). The experiment was superimposed on eight years old trees which were planted in July 2005 and grown under uniform shade of Sesbania sesban.

Table 1. Geographical origin of the coffee (Coffea ararica L.) germplasm accessions at Agaro research station.

\begin{tabular}{|c|c|c|c|c|c|}
\hline Collection No. & Zone & Woreda & Peasant Association & Specific Location & Altitude (m) \\
\hline $\mathrm{L}-1 / 2004$ & Jimma & Gomma & Choche Lemi & Meto & 1500 \\
\hline $\mathrm{L}-2 / 2004$ & Jimma & Gomma & $>$ & $>>$ & 1500 \\
\hline L-3/ 2004 & Jimma & Gomma & $>$ & $>>$ & 1500 \\
\hline L-5/ 2004 & Jimma & Gomma & $>$ & $\gg$ & 1510 \\
\hline L-6/ 2004 & Jimma & Gomma & $>$ & $>>$ & 1500 \\
\hline $\mathrm{L}-7 / 2004$ & Jimma & Gomma & $>$ & Loko & 1460 \\
\hline L-9/ 2004 & Jimma & Gomma & $>$ & $>>$ & 1460 \\
\hline L-10/ 2004 & Jimma & Gomma & $>$ & $>>$ & 1460 \\
\hline L-11/ 2004 & Jimma & Gomma & $>$ & $>>$ & 1450 \\
\hline L-12/ 2004 & Jimma & Gomma & $>$ & GiYo & 1540 \\
\hline L-13/ 2004 & Jimma & Gomma & $>$ & $>>$ & 1510 \\
\hline L-14/ 2004 & Jimma & Gomma & $>$ & $>>$ & 1510 \\
\hline L-15/ 2004 & Jimma & Gomma & $>$ & $>>$ & 1510 \\
\hline L-16/ 2004 & Jimma & Gomma & $>$ & Wode/andode & 1520 \\
\hline L-18/ 2004 & Jimma & Gomma & $>$ & $>>$ & 1500 \\
\hline L-19/ 2004 & Jimma & Gomma & $>$ & $>>$ & 1500 \\
\hline L-20/ 2004 & Jimma & Gomma & $>$ & $>$ & 1500 \\
\hline L-21/ 2004 & Jimma & Gomma & $>$ & Bonsile & 1540 \\
\hline
\end{tabular}




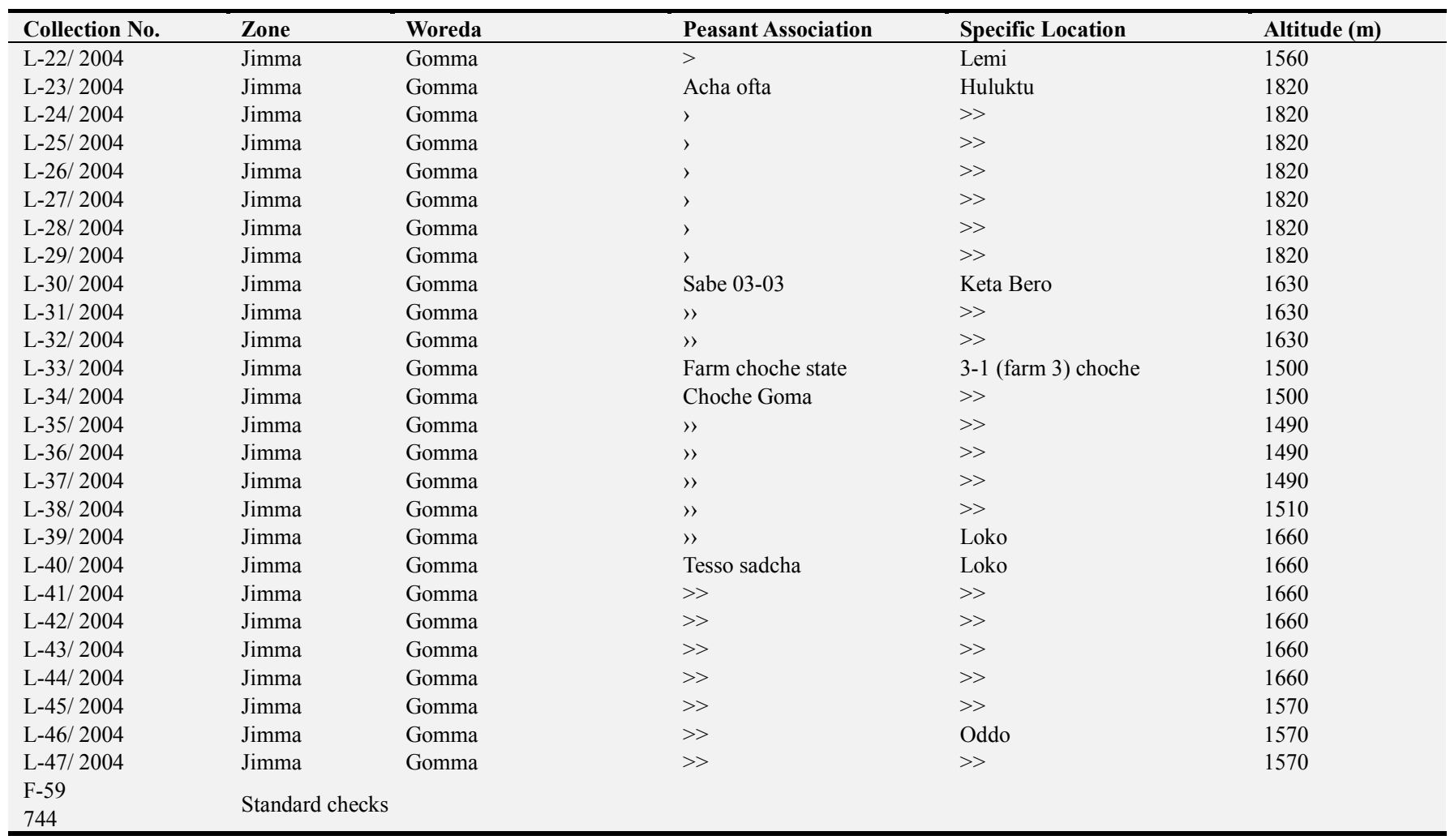

\subsection{Experimental Design, Management and Season}

The study was conducted from $2004 / 5$ to $2013 / 14$ cropping season. The experiment was laid out in single non-replicated plot. Spacing between trees and plots was two meter. All the agronomic practices were applied uniformly according to the recommendations [9].

\subsection{Data Collected}

Data were collected on nine quantitative traits using the coffee descriptors of international plant genetic resource institute (IPGRI, 1996) (Table 2).

Table 2. Quantitative characters studied and their descriptions as per IPGRI descriptor of 1996.

\begin{tabular}{|c|c|c|c|}
\hline & Characters & Unit & Description \\
\hline 1 & Height up to first primary branch & $\mathrm{Cm}$ & This character was measured using a tape meter from the ground to first primary branch \\
\hline 2 & Total plant height & $\mathrm{Cm}$ & This character was measured from the ground level to the tip of the tree using a tape meter \\
\hline 3 & Girth & $\mathrm{Cm}$ & The diameter of the main stem was measured at five $\mathrm{cm}$ above the ground using a digital caliper \\
\hline 5 & Number of primary branches & No & Total number of primary branches were counted per tree \\
\hline 6 & Number of main stem nodes & no. & This was recorded by counting number of nodes from bottom to the top of the tree \\
\hline 7 & Average inter node length of main stem node & $\mathrm{Cm}$ & $\begin{array}{l}\text { This was computed per tree as }(\mathrm{TPH}-\mathrm{HUP}) / \mathrm{NMSN}-1 \text {, where } \mathrm{TPH}=\text { total plant height, HUP } \\
=\text { height up to first primary branch, } \mathrm{NMSN}=\text { number of main stem nodes }\end{array}$ \\
\hline 8 & Canopy diameter & $\mathrm{Cm}$ & $\begin{array}{l}\text { This was measured in cm using tape meter from east-west and north- south and taking the } \\
\text { average as }(\mathrm{EW}+\mathrm{NS}) / 2\end{array}$ \\
\hline 9 & Yield per hectare & Qt & $\begin{array}{l}\text { Weight of fresh cherries per tree was recorded and converted into clean coffee per hectare. } \\
\text { Finally, five years mean yield data were used for analysis }\end{array}$ \\
\hline
\end{tabular}

\subsection{Data Analysis}

The variability among genotypes was assessed using descriptive statistics tools such as mean, range and standard deviation. Hierarchical clustering was employed using the similarity coefficients among the 49 coffee genotypes. Clustering was performed by employing the method of average linkage clustering strategy and the appropriate numbers of clusters were determined from the values of Pseudo F and Pseudo $\mathrm{T}^{2}$ statistics.

Genetic divergence between clusters was determined using the generalized Mahalanobis's $D^{2}$ statistics [14] using the equation: $D^{2} p=((X i-X j) S-1(X i-X j)$.

Where: $D_{p}^{2}=$ the distance between any two groups $i$ and $j$;

$\mathrm{X}_{\mathrm{i}}$ and $\mathrm{X}_{\mathrm{j}}=$ the $\mathrm{p}$ mean vectors of accessions ${ }_{\mathrm{i}}$ and $\mathrm{j}_{\mathrm{j}}$, respectively.

$\mathrm{S}^{-1}=$ the inverse of the pooled covariance matrix.

The D2 values obtained in this study for pairs of clusters were considered as the calculated values of Chi-square (X2) and were tested for significance both at $1 \%$ and $5 \%$ probability levels against the tabulated value of $\mathrm{X} 2$ for ' $\mathrm{P}$ ' degree of freedom, where $\mathrm{P}$ is the number of characters 
considered [21]. The dendrogram was built based on the average linkage method. Principal component analysis was performed to assess the contribution of each morphological character in grouping the 49 coffee accessions. Clustering, genetic divergence and principal component analysis were performed using SAS version 9.3 [19].

\section{Results and Discussion}

\subsection{Range and Mean Value}

The range, mean and standard deviation of nine morphological traits of 49 Limu coffee germplasm accessions is presented in Table 3 . In general, genotypes showed wider range for different morphological traits. Total plant height ranged from 207 to $361 \mathrm{~cm}$ with an average of $263.27 \mathrm{~cm}$. Likewise, height up to first primary branches ranged from 17.6 to $37.8 \mathrm{~cm}$ with an average of $28.14 \mathrm{~cm}$ (Table 3). Stem diameter (Girth) also ranged from 3.8 to $5.4 \mathrm{~cm}$ with an average of $5.08 \mathrm{~cm}$. Length of the longest primary branch, number of primary branches and number of main stem nodes ranged from 66.7- 117.7, 53.2-86 and 27.8-45.2, respectively. Besides, average internode length of main stem, average canopy diameter and coffee yield also showed wider range of 5.63-8.15,.155.4- 204.5 and 3.09- 19.17, respectively.

The presence of a wide range between minimum and maximum values for each trait indicates the existence of considerable variation among the germplasm accessions studied (Table 3). Such variation in the coffee germplasm collection is an opportunity for coffee researchers to improve traits of interest through parent selection, hybridization and recombination of desirable genotypes [1].

In this study, different genotypes showed best performance for each trait, for example, L42/2004 was the tallest genotype. The check variety, F-59, showed the highest stem diameter (Girth) and yield. Similarly, among the tested accessions, L32/2004 showed the highest values for height up to the first primary branches and average canopy diameter. Moreover, L35/2004 showed the highest values for number of primary branches and main stem nodes. L23/2004 and L39/2004 showed the highest values for length of the first primary branch and average internode length of the main stem node, respectively.

Table 3. Range, mean and standard deviation of the nine morphological characters in 49 Limu coffee accessions tested at Agaro.

\begin{tabular}{|c|c|c|c|}
\hline Characters & Range & Mean & Std. \\
\hline TPH $(\mathrm{cm})$ & 207 for L34/2004 - 361 for L42/2004 & 263.27 & 30.54 \\
\hline HUFPB $(\mathrm{cm})$ & 17.6 for $L 02 / 2004-37.8$ for $L 32 / 2004$ & 28.14 & 3.8 \\
\hline GIRTH $(\mathrm{cm})$ & 3.8 for $L 09 / 2004-5.74$ for $F-59$ & 5.08 & 0.40 \\
\hline LLFPB $(\mathrm{cm})$ & 66.7 for $744-117.7$ for $L 23 / 2004$ & 91.01 & 11.48 \\
\hline NPB (no.) & 53.2 for $\mathrm{L} 38 / 2004-86$ for $\mathrm{L} 35 / 2004$ & 67.88 & 6.36 \\
\hline NMSN (no.) & 27.8 for $L 38 / 2004-45.2$ for $L 35 / 2004$ & 35.38 & 3.44 \\
\hline AILMS $(\mathrm{cm})$ & 5.63 for $\mathrm{L} 15 / 2004-8.15$ for $\mathrm{L} 39 / 2004$ & 6.63 & 0.60 \\
\hline Yield (qt/ha) & 3.09 for $L 09 / 2004-19.17$ for F-59 & 10.31 & 3.43 \\
\hline
\end{tabular}

$\mathrm{TPH}=$ total plant height, HUFPB = height up to first primary branch, LLFPB= length of longest first primary branch, $\mathrm{NPB}=$ number of primary branches, $\mathrm{NMSN}=$ number of main stem node, $\mathrm{AILMS}=$ average internode length of main stem, $\mathrm{ACD}=$ average canopy diameter. $\mathrm{CY}=$ coffee yield and $\mathrm{Std} .=$ standard deviation.

Table 4. Diversity classes for 49 coffee germplasm accessions studied for nine quantitative traits at Agaro.

\begin{tabular}{|c|c|c|c|}
\hline Clusters & No. of gen. & Proportion & Genotypes \\
\hline I & 21 & 42.86 & $\begin{array}{l}\mathrm{L} 27 / 2004, \mathrm{~L} 47 / 2004, \mathrm{~L} 44 / 2004, \mathrm{~L} 16 / 2004, \mathrm{~L} 18 / 2004, \mathrm{~L} 10 / 2004, \mathrm{~L} 11 / 2004, \mathrm{~L} 13 / 2004, \mathrm{~L} 40 / 2004, \mathrm{~L} 31 / 2004, \\
\mathrm{~L} 32 / 2004, \mathrm{~L} 25 / 2004, \mathrm{~L} 262004, \mathrm{~L} 39 / 2004, \mathrm{~L} 07 / 2004, \mathrm{~L} 14 / 2004, \mathrm{~L} 46 / 2004, \mathrm{~L} 41 / 2004, \mathrm{~L} 45 / 2004, \mathrm{~L} 35 / 2004 \\
\text { and L24/2004 }\end{array}$ \\
\hline II & 25 & 51.02 & $\begin{array}{l}\text { L08/2004, L22/2004, L04/2004, L06/2004, L15/2004, L17/2004, L19/2004, L21/2004, L20/2004, L30/2004, } \\
\text { L36/2004, L37/2004, L282004, L05/2004, L38/2004, L12/2004, L29/2004, L03/2004, L02/2004, L33/2004, } \\
\text { 49(744), 48(F-59), L34/2004, L09/2004 and L01/2004 }\end{array}$ \\
\hline III & 3 & 6.12 & $\mathrm{~L} 42 / 2004, \mathrm{~L} 43 / 2004, \mathrm{~L} 23 / 2004$ \\
\hline
\end{tabular}

\subsection{Cluster Analysis}

The $\mathrm{D}^{2}$ value based on the mean value of coffee germplasm accessions resulted in classifying the 49 accessions into three groups Table 4 . This indicates that, the tested coffee germplasm accessions are moderately divergent. Cluster II was the largest with 25 germplasm accessions $(51.02 \%)$ followed by cluster I with 21 germplasm accessions $(42.86 \%)$ of the total coffee accessions. However, the third cluster had only three accessions $(6.12 \%)$. In this study, accessions collected from different collection sites were grouped together, for instance, accessions collected from all collection sites were clustered together in cluster I. In support of this, Bayetta [3] reported that morphological variation is more important than variation in geographic origin as indicator of genetic diversity in coffee. Seyoum (2003) has also reported that accessions collected from Gambella, Kullo, Keffa, Illubabor, Wello, Wellega, Maji, Harar, and Sidamo were clustered together, despite the fact that the accessions were collected from different geographic 
origins. In addition, in the present study, accessions collected from the same kebeles were clustered into different clusters, suggesting the existence of genetic diversity within each collection sites. Lemi and Ashenafi [13] also reported that, accessions collected from different origins were clustered together. Therefore, this diversity could be exploited further to increase the genetic base of specialty coffee varieties for each coffee producing agro ecologies in the country.

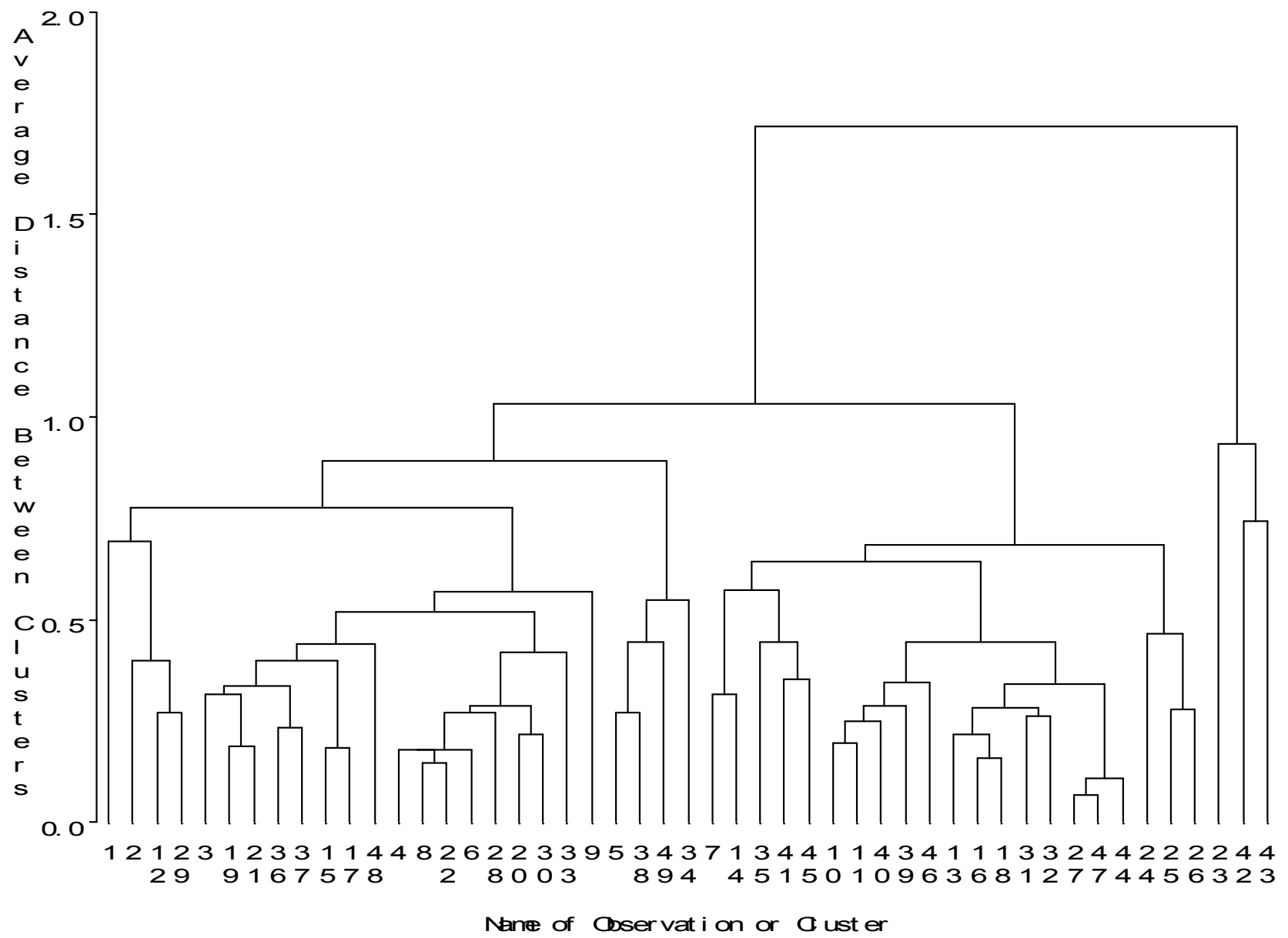

Figure 1. Dendrogram showing similarities among 49 coffee germplasm accessions evaluated for nine quantitative traits.

\subsection{Cluster Mean Characterization}

The clusters mean for nine characters (Table 5) revealed that, the cluster III with three accessions had the highest mean values for the characters namely; total plant height, height up to first primary branches, girth, length of the longest first primary branches, number of primary branch, number of main stem nodes and coffee yield. Therefore, the coffee accessions grouped under this cluster may serve as suitable source for these traits for future breeding purpose. Besides, cluster I with 21 coffee accessions had the highest mean values for the character of average internode length of the main stem and average canopy diameter but coffee accessions grouped under this cluster had the lowest mean values for other traits. On the other hand, cluster II with 25 coffee accessions had medium values for the nine morphological characters investigated. From the present study, it can be concluded that hybridization between the genotypes belonging to clusters showing maximum divergence and complementarity for traits of interest will lead to accumulation of genes in a single variety. Therefore, using the mean value of clusters for different characters and performance of the genotypes grouped in the respective cluster could be useful to design viable hybridization programme for improvement of particular trait of coffee.

Table 5. Mean values of nine quantitative traits for three clusters of 49 coffee germplasm accessions tested at Agaro.

\begin{tabular}{|c|c|c|c|}
\hline \multirow{2}{*}{ Characters } & \multicolumn{3}{|l|}{ Clusters } \\
\hline & Cluster I & Cluster II & Cluster III \\
\hline ТPH & 281 & $239.70^{*}$ & $335.63^{* *}$ \\
\hline HUFPB & 28. 10 & $28.01^{*}$ & $29.53^{* *}$ \\
\hline GIRTH & 5.17 & $4.97^{*}$ & $5.43^{* *}$ \\
\hline LLFPB & 89.25 & $92.14^{*}$ & $93.93^{* *}$ \\
\hline NPB & 70.43 & $64.73^{*}$ & $76.27^{\text {** }}$ \\
\hline NMSN & 36.54 & $33.89^{*}$ & $39.87^{* *}$ \\
\hline AILMS & $6.97^{* *}$ & $6.31^{*}$ & 6.92 \\
\hline $\mathrm{ACD}$ & $179.24^{* *}$ & $173.05^{*}$ & 175 \\
\hline CY & 10.24 & $9.98^{*}$ & $13.51^{* *}$ \\
\hline
\end{tabular}

$\mathrm{TPH}=$ total plant height, $\mathrm{HUFPB}=$ height up to first primary branch, $\mathrm{LLFPB}=$ length of the longest first primary branch, NPB $=$ number of primary branches, $\mathrm{NMSN}=$ number $\mathrm{f}$ main stem node, $\mathrm{AILMS}=$ average internode length of main stem, $\mathrm{ACD}=$ average canopy diameter. $\mathrm{CY}=$ coffee yield. $* *$ and $*$ represent higher and lower cluster mean values, respectively. 


\subsection{Genetic Divergence Analysis}

Genetic divergence as measured by Mahalanobis [14] generalized distance $\left(\mathrm{D}^{2}\right)$ has been known as one of the important statistical tools to provide a rational basis for selection of parents in hybrid variety development programs. Mahalanobis distance $\left(\mathrm{D}^{2}\right)$ of the three clusters of 49 coffee germplasm accessions based on nine quantitative traits is presented in Table 6.

The inter cluster distance ranged from 13.09 to 44.08 . The largest distance between the clusters were detected between cluster II and III (44.08), and I and III (17.87), while the shortest distance was observed between cluster I and II (13.09). The chi-square test indicates that there were significant inter-cluster distances between cluster I and III, and II and III. This indicated that the genotypes present in these clusters may give a high heterotic response and better segregants [14]. Similar results have been reported on Limmu coffee accessions [18, 10, 13]. However, there was no significant inter-cluster distance between cluster I and II, indicating that crossing genotypes from these clusters would not result in hetrosis due to the low level of heterozygosity. Hybridization between the genotypes of distant clusters is likely to generate superior and transgressed segregants. Therefore, while selecting parents for hybridization program, inter cluster distances essential to be taken into consideration.

Table 6. Inter-cluster distances for 49 coffee germplasm accessions studied for nine quantitative traits.

\begin{tabular}{llll}
\hline Clusters & I & II & III \\
\hline I & 0 & $13.09^{\text {ns }}$ & $17.87^{*}$ \\
II & & 0 & $44.08^{* *}$ \\
II & & & 0 \\
\hline
\end{tabular}

$* *=$ Highly Significant at $\mathrm{P}=0.01(\chi 2)=21.67, *=$ Significant at $\mathrm{P}=0.05(\chi$ $2)=16.92, \mathrm{Ns}=$ non - significant at $\mathrm{P}=0.05(\chi 2)=16.92$.

\subsection{Principal Component Analysis}

Using Eigenvalue greater than one as a measure for significance of a principal component (PC), four PCs extracted about $82 \%$ of the total variance of the 49 coffee germplasm accessions (Table 7). Among these, the first three PCs explained about $70 \%$ of the variance. Likewise, the second PC accounts for about $20 \%$ of the total variance, mainly from variations in average inter-node lengths of the main stem, length of the longest primary branches, number of main stem nodes and number of primary branches. The third principal component accounted for $16 \%$ of the total variation. Length of the longest first primary branch, height up to the first primary branches, average canopy diameter and average internode length of the main stem played major role for the differentiation among the accessions. The major contributors to the fourth PC accounts for about $12 \%$ of the total variance were average internode length of the mainstem, height up to first primary branches and total plant height. Generally, the PC analysis confirmed that moderate diversity of the coffee germplasm accessions since the entire variation cannot be explained in this few PCs. This, in turn, indicates the involvement of a number of traits in contributing towards the overall diversity. The contribution of several morphological traits to the overall variation in coffee accessions was also observed in other similar studies $[16,18,10,16]$.

Table 7. Eigenvectors and eigenvalues of the first four principal components $(P C)$ of nine quantitative traits of coffee germplasm accessions collected from Limu.

\begin{tabular}{lllll}
\hline Characters & PC1 & PC2 & PC3 & PC4 \\
\hline TPH & 0.44 & 0.01 & 0.28 & 0.39 \\
HUFPB & -0.04 & 0.26 & 0.47 & -0.49 \\
GIRTH & 0.41 & 0.27 & 0.04 & -0.31 \\
LLFPB & 0.01 & 0.41 & -0.55 & 0.11 \\
NPB & 0.50 & -0.32 & -0.04 & -0.03 \\
NMSN & 0.48 & -0.35 & -0.07 & 0.01 \\
AILMS & 0.03 & 0.43 & 0.36 & 0.64 \\
ACD & 0.28 & 0.37 & -0.46 & -0.03 \\
CY & 0.27 & 0.38 & 0.20 & -0.28 \\
Eigenvalue & 3.07 & 1.79 & 1.44 & 1.05 \\
Proportion & 0.34 & 0.20 & 0.16 & 0.12 \\
Cumulative & 0.34 & 0.54 & 0.70 & 0.82 \\
\hline
\end{tabular}

$\mathrm{TPH}=$ total plant height, $\mathrm{HUFPB}=$ height up tp first primary branch, $\mathrm{LLFPB}=$ length of the longest first primary branch, $\mathrm{NPB}=$ number of primary branches, $\mathrm{NMSN}=$ number $\mathrm{f}$ main stem node, $\mathrm{AILMS}=$ average internode length of main stem, $\mathrm{ACD}=$ average canopy dieter. $\mathrm{CY}=$ coffee yield and PC1-PC4= principal components.

\section{Conclusion}

The $\mathrm{D}^{2}$ value based on the mean value of coffee germplasm accessions resulted in classifying the coffee accessions into three distinct clusters. The significant intercluster distances between clusters in this study indicated that there is a high opportunity for obtaining transgressive segregates and maximize heterosis by crossing germplasm accessions belonging to these clusters. Therefore, grouping of accessions by multivariate methods could be of considerable practical value to the coffee breeders so that representative accessions could be chosen from such clusters for hybridization programs. Moreover, despite all traits contributes for the observed variability, number of primary branches, number of main stem nodes, total plant height and girth explained the lion share for the variability of coffee accessions and could be used as a selection criterion for improving the production and productivity of the crop.

\section{References}

[1] Ahmed, S. 2013. Study on genetic diversity in maize (Zea mays L.) inbred lines for the development of hybrids, $\mathrm{PhD}$ Thesis, Department of Genetics and Plant Breeding, Bangladesh Agricultural University, Banglade.

[2] Ayana, G., Abdo, A., Merine, Y., Jobie, T., Bekele, A., Mekonnen, D., Mekibib, F., Tabor, G., Amare, M. and Eshete, M., 2016. Plant variety release. Protection and seed quality control directorate. 
[3] Bayetta, B., 2001. Arabica coffee breeding for yield and resistance to Coffee Berry Disease (Colletotichum Kahawae) sp. nor). APhD dissertation submitted to the Imperial College of Wye University of London. 272p.

[4] Chauhan, M. P., Mishra, A. C. and Singh, A. K., 2008. Genetic divergence studies in murd bean (Vigna mungo L.). Legume Research-An International Journal, 31 (1): 63-67.

[5] Davis, A. P., Govaerts, R., Bridson, D. M. and Stoffelen, P. (2006). An annotated taxonomic conspectus of the genus Coffea (Rubiaceae). Botanical Journal of the Linnean Society. 465-512.

[6] Desalegn Aemayehu. 2018. Genetic variability and character association of Amaro Kello coffee (Coffea arabica L.) Accessions at Awada, southern Ethiopia., MSc thesis, Jimma university, pp. 88.

[7] EBI (Ethiopian Biodiversity Institute). 2014. Ethiopia's Fifth National Report to the Convention on Biological Diversity. Addis Ababa, Ethiopia. 86p.

[8] Elias, A. 2005. Economics of coffee bean marketing. A case study of Gomma district in Jimma zone of Ethiopia.

[9] Endale Taye, Taye Kufa, Antenhe Nestre, Tesfaye Shimber, Alemseged Yilma and Tesfaye Ayano, 2008. Research on coffee field management. pp. 187-195. In: Girma Adugna, Bayetta Belachew, Tesfaye Shimber, Endale Taye and Taye Kufa (eds.). Coffee Diversity and Knowledge. Proceedings of a National Workshop Four Decades of Coffee Research and Development in Ethiopia, 14-17 August 2007, Addis Ababa, Ethiopia.

[10] Getachew. WeldeMichael, sentayehu Alamerew and Tye Kufa., 2013. Genetic diversity analysis of some Ethiopian specialty coffee (Coffea arabica L.) germplasm accessions based on morphological traits.

[11] IPGRI (International Plant Genetic Resource Institute) 1996. Diversity for development. Rome, International Plant Genetic Resources Institute.

[12] Jain, S. K., Qualset, C. O., Bhatt, G. M and Wu, K. K. 1975. Geographical pattern of phenotypic diversity in a world collection of durum wheat. Crop Science 15: 700-704.

[13] Lemi B., and Ashenafi A., 2016. Multivariate Analysis Study of Limmu Coffee (Coffea arabica L.) Accessions in South Western Ethiopia. Agricultural Science Research Journal, 6 (7): 166-174.
[14] Mahalanobis, P. C., 1936. On the generalized distance in statistics. J. Genet. 41: 159-193.

[15] Masreshaw, Y. 2018. Genetic variability in Yayu coffee (Coffea arabica $\mathrm{L}$ ) germplasm at Metu, southwestern Ethiopia (Msc. thesis, Jimma University) 87p.

[16] Mesfin Kebede and Bayetta Bellachew., 2008. Phenotypic Diversity in the Hararge Coffee (Coffea arabica L) Germplasm for Quantitative Traits. East African Journal of Sciences, 2 (1): 13-18.

[17] Mesfin Kebede, Bayetta Bellachew and Musa Jarso. 2015. Multivariate analysis of phenotypic diversity in the South Ethiopian coffee (Coffea arabica L.) for quantitative traits. Advances in Crop Science and Technology, pp. 1-4.

[18] Olika, Kitila., Sentayehu, Alamerew., Taye, Kufa. and Weyessa, Garedew., 2011. Variability of quantitative traits in Limmu coffee (Coffea arabica L.) in Ethiopia. International journal of agricultural research, 6 (6): 482-493.

[19] SAS (Statistical Analysis System) software. 2011. SAS Institute, Cary, NC, USA.

[20] Seyoum Seifu, 2003. Genetic divergence for seedling parameters and associations among agronomic traits in the Ethiopian coffee (Coffea arabica L.) germplasm. An MSc thesis submitted to the School of graduate studies of Alemaya University.

[21] Singh,. R. K. and B. D. Chaudhary. 1987. Biometrical methods in quantitative genetic analysis. Kalyani publishers, New Delhi-Ludhiana, India. 318p.

[22] Sylvain, P. G. 1958. Ethiopian Coffee: Its significance to world coffee problems. Botany 12: 111-139.

[23] Tadesse W. G., 2015. Environment and coffee forest forum. Coffee: Ethiopia's gift to the world, the traditional production systems as living examples of crop domestication, and sustainable production and an assessment of different certification schemes. Addis Ababa, Ethiopia.

[24] Taye Kufa, 2010. Environmental Sustainability and Coffee Diversity in Africa. http://dev.ico.org/event pdfs/wcc2010/presentationswcc2010-kufa-notese-pdf/accessed date November 10/2011/

[25] United States Department of Agriculture (USDA), 2020. Coffee annual report: GAIN (Global Agricultural Information Network) USDA foreign Agricultural Service report Number: ET2020-0004. 